\title{
Structure of parasite cenosis of endoparasitoses of ruminants
}

\author{
E.S. Klimova*, A.D. Reshetnikova, T.V. Babintseva, and T.G. Krylova \\ FSBEI HE Izhevsk SAA, Izhevsk, Russia
}

\begin{abstract}
The infestation was studied and the structure of the parasite cenosis of ruminants of the Udmurt Republic was characterized. Over the period of several years of research (2016-2020), a diverse parasitophauna was identified. According to the results of the research, it was established that cattle is mainly invaded by Eimeria spp., nematodes of the Strongylata suborder, dicroceliosis dominates from trematode infestations. The maximum infection rate was noted by eimeriosis invasion, during the entire time of the studies it varied from $87.84 \%$ to $77.73 \%$, which indicates a tendency to increase invasion and stationary problems of farms. The features of competitive relationships are clearly traced in hepatic flukes: dicrocoeliums and fascioles. Dicrocoeliotic invasion prevails on average by $32 \%$, which indicates a partial manifestation of antagonism. When analyzing the generic structure of the parasite complex of cattle, on average for five years, it was found that the largest share is occupied by Eimeria spp - 44.35, Strongylata - 30.52, Dicrocoelium - 17.52, Fasciola - 6.43, Eurythrema 0.67 and Trichostrongylus -0.51 are less represented. A retrospective epizootic analysis of parasitoses showed that sheeps, like cattle, have a diverse parasitophauna, but in the first case, the detection of monoinvasions is 3.5 times higher. In the structure of sheep parasite cenosis, similar indicators of infection with Eimeria spp, Strongyloides, Moniezia were found, generic indices ranged from 24.18 to 27.61. Strongylatosis of the gastrointestinal tract are replaced by Strongyloides. A significant change was also observed in the group of trematode infestations. Unlike cattle, fasciolosis prevails in sheep with a maximum value of 9.5 times in 2019 , while dicroceliosis was not registered at all in 2017. In the sheep parasite complex, moniesiosis occupies the main share -27.61 , which may be related to the conditions of keeping, since sheeps are grazing for a long time and a meeting with intermediate hosts - oribatid mites is inevitable.
\end{abstract}

\section{Introduction}

Helminthiasis and protozoasis of ruminants can have a fairly significant effect on the violation of the physiological state of animals $[6-8,15]$, subsequently this is reflected in a decrease in the level of dairy and meat productivity, the growth rate of young animals and other indicators [6-8]. Unfortunately, the prevention of invasive diseases does not receive due attention from managers and veterinarians of farms, despite the wide variety of

\footnotetext{
* Corresponding author: catia.calinina2012@yandex.ru
} 
anthelmintic 7 preparations $[9-10,12,14]$. In this regard, it is very important to conduct regular helminthological studies of fecal samples to identify pathogens [17].

Parasitosis of ruminants is widespread in the conditions of both industrial and private cattle breeding of the Udmurt Republic, and beyond its borders [5]. The analysis of the parasitic environment allows to reflect the degree of infection of animals, to determine the species diversity of pathogens and their structure $[1,4,11]$. In addition, constant monitoring allows to more carefully develop measures for the prevention and control of invasive diseases, which will be based on knowledge of the generic identity of pathogens, and as a result, influence the choice of both anthelmintic preparations and measures to prevent reinvasion $[9-10,12,14,16]$.

When studying fecal samples from cattle and sheeps, we often encounter not monoinvasion, but an association of pathogens. The available parasitic indices may not fully reflect the ratio of various representatives of invasive diseases within the farm. In this regard, after studying a number of works [3-4], which discuss the need to introduce a new nosological unit reflecting the density of a species, genus or other taxonomic unit in the structure of parasite cenosis, we used such an indicator as the parasite cenosis index. The parasite cenosis index reflects the structure of helminthocenosis in the proportions of a particular pathogen. This allows to fully assess the impact that each pathogen has on the host body during mixed invasions.

The purpose of this work was to determine the species density of various invasive diseases and the structure of parasite cenosis of ruminants in the farms of the Udmurt Republic.

\section{Materials and methods}

Research works on the study of the prevalence of endoparasitosis of ruminants with the subsequent determination of the proportion of identified parasites in the structure of parasite cenosis in the territory of the Udmurt Republic were carried out in 2016-2020.

During the research, we selected and examined 2009 fecal samples, including 1520 samples from cattle and 489 samples from sheeps from 6 farms and 4 districts of Udmurtia.

Helminthoscopy was carried out on the day of material collection on the basis of the parasitological laboratory of the Department of Infectious Diseases and Pathological Anatomy of the FSBEI HE Izhevsk State Agricultural Academy, by the method of helminthoscopy according to Fulleborn, Kotelnikov-Khrenov and helmintholarvoscopy according to Berman-Orlov. According to the results of the studies, the extent of invasion was calculated (EI,\%). The average number of eggs in fecal samples was not calculated, since moniezias have a closed uterus, then segments or fragments of the cestode body are released into the external environment.

To determine the structure of parasite cenosis and the share of each representative, the parasite cenosis index was used, which was calculated for each pathogen separately according to the following formula:

$$
I P=\frac{E I i}{\sum E I} * 100 \%
$$

where $I P$ is the index of parasite cenosis

$E I i$ - the extent of invasion of a single species, genus

$\sum E I$ is the sum of the indicators of the extensities of invasion of individual species and genera [3-4]. 


\section{Results}

The analysis of the results of helminthic-ovolarvascopic studies showed that helminthicprotozoal infestations were recorded among cattle and sheeps in all the studied regions of the republic $[1,4,11]$. In the studied enterprises, a sufficiently high biodiversity of pathogens was revealed, but their ratio varies significantly, which may indicate the phenomena of interspecific competition. During the study, we found eggs and oocysts of pathogens of 8 genera belonging to the Protozoa subfamily, classes Cestoda, Trematoda, Nematoda (Table $1,3)$.

Table 1. Indicators of the invasion extensiveness of cattle endoparasitoses, (\%)

\begin{tabular}{|l|c|c|c|c|c|c|c|c|c|c|}
\hline \multirow{2}{*}{$\begin{array}{l}\text { Pathogens } \\
\text { of diseases }\end{array}$} & \multicolumn{2}{|c|}{$\begin{array}{c}2016 \\
\text { (283 samples) }\end{array}$} & \multicolumn{2}{|c|}{$\begin{array}{c}2017 \\
(294 \text { samples })\end{array}$} & \multicolumn{2}{c|}{$\begin{array}{c}2018 \\
\text { (312 samples) }\end{array}$} & \multicolumn{2}{c|}{$\begin{array}{c}2019 \\
\text { (302 samples) }\end{array}$} & \multicolumn{2}{|c|}{$\begin{array}{c}2020 \\
\text { (329 samples) }\end{array}$} \\
\cline { 2 - 13 } & $\begin{array}{c}+ \\
\text { sam } \\
\text { ples }\end{array}$ & EI, \% & $\begin{array}{c}+ \\
\text { sam } \\
\text { ples }\end{array}$ & EI, \% & $\begin{array}{c}+ \\
\text { sam } \\
\text { ples }\end{array}$ & EI, \% & $\begin{array}{c}+ \\
\text { sam } \\
\text { ples }\end{array}$ & EI, \% & $\begin{array}{c}+ \\
\text { samp } \\
\text { les }\end{array}$ & EI, \% \\
\hline Eimeriosis & 220 & 77.73 & 234 & 79.59 & 247 & 79.17 & 242 & 80.13 & 289 & 87.84 \\
\hline $\begin{array}{l}\text { Strongylat } \\
\text { osis of the } \\
\text { gastrointes } \\
\text { tinal tract }\end{array}$ & 153 & 54.06 & 148 & 50.34 & 163 & 52.24 & 189 & 62.58 & 194 & 58.97 \\
\hline $\begin{array}{l}\text { Dicrocelio } \\
\text { sis }\end{array}$ & 108 & 38.16 & 101 & 34.35 & 89 & 28.53 & 93 & 30.79 & 94 & 28.57 \\
\hline $\begin{array}{l}\text { Fascioliasi } \\
\text { s }\end{array}$ & 55 & 19.43 & 49 & 16.67 & 42 & 13.46 & 12 & 3.97 & 19 & 5.78 \\
\hline $\begin{array}{l}\text { Eurytrema } \\
\text { tosis }\end{array}$ & 7 & 2.47 & 8 & 2.72 & - & - & 3 & 0.99 & - & - \\
\hline $\begin{array}{l}\text { Trichocep } \\
\text { halosis }\end{array}$ & 3 & 1.06 & 5 & 1.70 & 4 & 1.28 & - & - & 2 & 0.61 \\
\hline
\end{tabular}

In the farms of the Udmurt Republic, cattle is mainly invaded by Eimeria spp., nematodes of the Strongylata suborder, dicroceliosis dominates among trematode infestations. Endoparasitoses of cattle are recorded in all research periods. Moreover, the extensiveness of livestock invasion is quite high, with the exception of eurythrematosis and trichocephalosis, which allows to talk about the disadvantage of farms for the detected diseases. The relatively low occurrence of pathogens of eurythrematosis and trichocephalosis can be associated with spontaneous natural infection of animals on walking grounds, or with imported feed.

In the cattle farms of the republic, parasites of the gastrointestinal tract are ubiquitous. The maximum invasiveness was noted by eimeriosis invasion, which during the entire time of the studies it varied from $87.84 \%$ to $77.73 \%$, which indicates a tendency to increase invasion and stationary problems of farms.

The level of infection with strongylatoses of the gastrointestinal tract is 1.5 times lower on average compared to coccidia. Trichocephalosis was detected in isolated cases, although considering the localization of pathogens (trichocephaluses - the thick section, strongylates of the gastrointestinal tract - the small intestine), they do not have an overwhelming effect on each other, which can lead to a favorable development of the biology of both representatives.

With mixed invasions, the population density of individual trematode species decreases compared to the indicators for individual types of invasions. The features of these competitive relationships are clearly traced in hepatic flukes: dicrocoeliums and fascioles. Dicrocoeliotic 
invasion prevails on average by $32 \%$, which indicates a partial manifestation of antagonism [2]. The eurythrematosis extensiveness did not exceed $2.72 \%$ in 2017.

This type of cattle infection in Udmurtia is formed due to favorable conditions for feeding and keeping animals. Animals are not grazed, which leads to increased exploitation of livestock premises, contamination, and circulation of eggs (oocysts) in the external environment.

A sharp decrease in the ambient temperature and a prolonged absence of surface solid precipitation (snow), lead to the rapid death of intermediate hosts of trematodes.

The analysis of the generic structure of the parasite complex of cattle of the Udmurt Republic for an average of five years is presented in Table 2, Figure 1.

Table 2. Structure of parasite cenosis of cattle.

\begin{tabular}{|l|c|c|c|c|c|c|}
\hline \multirow{2}{*}{ Pathogen } & \multicolumn{5}{|c|}{ Generic Parasitism Index (GPI) } \\
\cline { 2 - 7 } & 2016 & 2017 & 2018 & 2019 & 2020 & $\begin{array}{c}\text { on average for 5 } \\
\text { years }\end{array}$ \\
\hline Eimeria spp & 40.30 & 42.93 & 45.32 & 44.9 & 48.32 & 44.35 \\
\hline Strongylata* & 28.02 & 27.16 & 29.91 & 35.07 & 32.44 & 30.52 \\
\hline Dicrocoelium & 19.78 & 18.53 & 16.34 & 17.25 & 15.72 & 17.52 \\
\hline Fasciola & 10.07 & 8.99 & 7.71 & 2.22 & 3.18 & 6.43 \\
\hline Eurythrema & 1.28 & 1.47 & 0 & 0.56 & 0 & 0.67 \\
\hline Trichostrongylus & 0.55 & 0.92 & 0.72 & 0 & 0.34 & 0.51 \\
\hline
\end{tabular}

Note * - pathogens of strongylatoses of the gastrointestinal tract

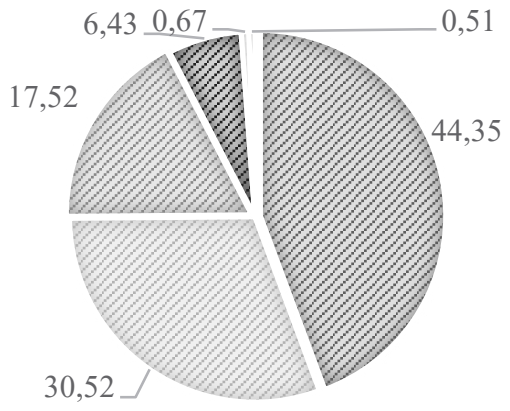

- Eimeria spp

Strongylata*

๑ Dicrocoelium

- Fasciola

Eurythrema

- Trichostrongylus

Fig. 1. Structure of parasite cenosis of cattle.

The largest share in the generic structure of the parasite complex is occupied by Eimeria spp. - 44.35, Strongylata - 30.52, Dicrocoelium -17.52, Fasciola - 6.43, Eurythrema - 0.67 and Trichostrongylus -0.51 are less represented. The proportion of eurythrems and trichocephaluses does not exceed one, but they are an important part for understanding the overall picture of the helminth fauna.

In cattle breeding enterprises, there is a high incidence of livestock in the form of pathogens of eimeriosis and strongylatosis of the gastrointestinal tract, and they occupy a significant part of the entire parasite cenosis.

A retrospective epizootic analysis of sheep parasitoses is presented in Table 3.

Table 3. Indicators of sheep invasion extensiveness, (\%)

\begin{tabular}{|c|c|c|c|c|c|}
\hline \multirow{2}{*}{$\begin{array}{c}\text { Pathogens } \\
\text { of diseases }\end{array}$} & \multicolumn{5}{|c|}{ Year and number of samples studied } \\
\cline { 2 - 6 } & $\begin{array}{c}2016 \\
\text { (97 samples) }\end{array}$ & $\begin{array}{c}2017 \\
\text { (83 samples) }\end{array}$ & $\begin{array}{c}2018 \\
\text { (105 samples) }\end{array}$ & $\begin{array}{c}2019 \\
\text { (92 samples) }\end{array}$ & $\begin{array}{c}2020 \\
\text { (112 samples) }\end{array}$ \\
\hline
\end{tabular}




\begin{tabular}{|l|c|c|c|c|c|c|c|c|c|c|}
\hline & $\begin{array}{c}+ \\
\text { samp } \\
\text { les }\end{array}$ & EI, \% & $\begin{array}{c}+ \\
\text { sampl } \\
\text { es }\end{array}$ & $\begin{array}{c}\text { EI, } \\
\%\end{array}$ & $\begin{array}{c}+ \\
\text { sample } \\
\text { s }\end{array}$ & EI, \% & $\begin{array}{c}+ \\
\text { sampl } \\
\text { es }\end{array}$ & EI, \% & $\begin{array}{c}+ \\
\text { sampl } \\
\text { es }\end{array}$ & EI, \% \\
\hline Eimeriosis & 37 & 38.15 & 41 & 49.40 & 33 & 31.43 & 29 & 31.52 & 52 & 46.43 \\
\hline $\begin{array}{l}\text { Strongylat } \\
\text { osis of the } \\
\text { gastrointest } \\
\text { inal tract }\end{array}$ & 13 & 13.40 & 8 & 9.64 & 16 & 15.24 & 5 & 5.43 & 18 & 16.07 \\
\hline $\begin{array}{l}\text { Strongyloi } \\
\text { dosis }\end{array}$ & 41 & 42.27 & 35 & 42.17 & 40 & 38.10 & 37 & 40.22 & 29 & 25.89 \\
\hline $\begin{array}{l}\text { Dicrocelios } \\
\text { is }\end{array}$ & 8 & 8.25 & - & - & 5 & 4.76 & 2 & 2.17 & 13 & 11.61 \\
\hline $\begin{array}{l}\text { Fascioliasi } \\
\text { s }\end{array}$ & 23 & 23.71 & 15 & 18.07 & 18 & 17.14 & 19 & 20.65 & 21 & 18.75 \\
\hline $\begin{array}{l}\text { Moniesiosi } \\
\text { s }\end{array}$ & 52 & 53.61 & 39 & 46.99 & 24 & 22.86 & 43 & 46.74 & 58 & 51.79 \\
\hline
\end{tabular}

In sheeps, as in cattle, the parasitophauna has a wide variety, but the detectability of monoinvasies is 3.5 times higher, which must be considered when planning and conducting antiparasitic treatments.

The structure of the sheep parasite complex is represented by 6 representatives (Table 4 , Fig. 2); unlike cattle, Eurythrema and Trichostrongylus are absent in the helminth complex. The maximum degree of infection with eimeriosis was $49.4 \%$. Such a high degree of livestock invasion by eimeriosis can be associated on the one hand with zoohygienic parameters that do not meet the normative indicators, and on the other hand with the lack of preventive and therapeutic treatments of animals. In this connection, they remain lifelong carriers and secrete oocysts into the environment, thereby being sources of invasion for young animals.

Table 4. Structure of sheep parasite cenosis.

\begin{tabular}{|l|c|c|c|c|c|c|}
\hline \multirow{2}{*}{ Pathogen } & \multicolumn{6}{|c|}{ Generic Parasitism Index (GPI) } \\
\cline { 2 - 7 } & 2016 & 2017 & 2018 & 2019 & 2020 & $\begin{array}{c}\text { on average for } \\
5 \text { years }\end{array}$ \\
\hline Eimeria spp & 21.27 & 29.71 & 24.27 & 21.48 & 27.23 & 24.79 \\
\hline Strongylata* & 7.47 & 5.80 & 11.77 & 3.70 & 9.42 & 7.63 \\
\hline Strongyloides & 23.56 & 25.36 & 29.41 & 27.41 & 15.18 & 24.18 \\
\hline Dicrocoelium & 4.60 & 0 & 3.67 & 1.48 & 6.81 & 3.31 \\
\hline Fasciola & 13.22 & 10.87 & 13.23 & 14.07 & 11.0 & 12.48 \\
\hline Moniezia & 29.89 & 28.26 & 17.65 & 31.86 & 30.37 & 27.61 \\
\hline
\end{tabular}

Note * - pathogens of strongylatoses of the gastrointestinal tract 


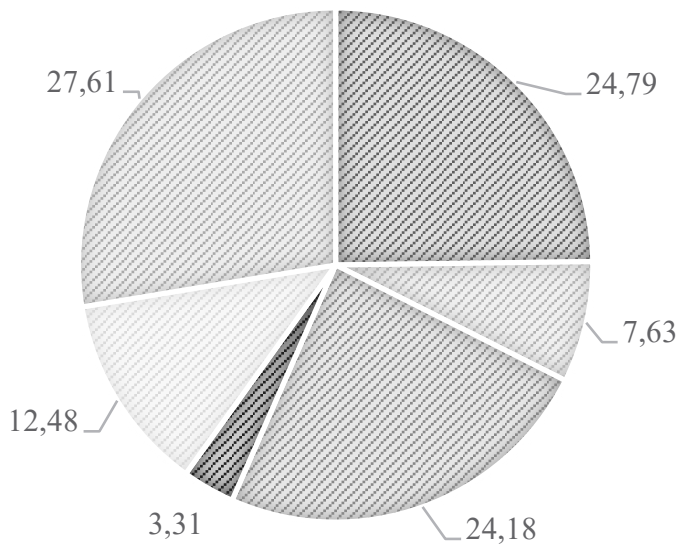

Eimeria spp

Strongylata*

- Strongyloides

- Dicrocoelium

Fasciola

Moniezia

Fig. 2. Structure of sheep parasite cenosis.

Analyzing the data in Table 4 and Figure 2, we found similar indicators of infection with Eimeria spp, Strongyloides, Moniezia, generic indices ranged from 24.18 to 27.61. Strongylatosis of the gastrointestinal tract are replaced by Strongyloides. A significant change was also observed in the group of trematode infestations, unlike cattle, fasciolosis prevails in sheep with a maximum value of 9.5 times in 2019 , while dicroceliosis was not registered in 2017.

In the structure of sheep parasite cenosis, moniesiosis occupies the main share - 27.61, which may be related to the conditions of keeping, since sheeps are grazing for a long time and a meeting with intermediate hosts-oribatid mites is not avoided. The share of coccidioses in the structure of parasite cenosis is at a high level and amounts to $24.79 \%$.

The joint parasitization of three consociates: moniesia, strongyloides and eimeria in the small intestine affected the strongylatoses of the gastrointestinal tract, which led to a decrease in invasion by almost $50 \%$.

\section{Discussion}

Analyzing the data obtained, we can say that on the territory of the Udmurt Republic, in the farms we studied, there is a high degree of infection of cattle with protozooses (eimeriosis), nematodes (strongylates of the gastrointestinal tract), pathogens of trematodoses, in sheeps, in addition to the above-mentioned pathogens, cestodoses - monesiosis are largely common. It is worth noting that the previously identified pathogens have high rates of extensiveness and intensity of invasion, which suggests that in almost all cases we are dealing with a mixed invasion. The reasons for this can be several factors: spontaneous infection of animals on walking grounds, constant circulation of the pathogen in the environment (eimeriosis); noncompliance with zoohygienic, sanitary norms and rules, leading to a decrease in the immune response, and, as a result, the inability of the body to eliminate the pathogen. Eimeriosis is a protozoan disease, the degree and intensity of invasion of which directly depends on the state of the body's immune system. In case of non-compliance with the norms of feeding, keeping animals, there is always a stress component, and, as a result, a decrease in the immune response, which safely affects the growth and development of the pathogen.

Calculating the indicator of parasite cenosis index will help to understand the structure of livestock invasion in the work of a practicing veterinarian. The index will help to assess the severity of the invasion and develop a prevention plan or therapeutic measures, as this is associated with the peculiarities of the biology of the pathogen development, as well as its 
share in the structure of parasite cenosis. In addition, this index will allow to evaluate the effectiveness of previously carried out measures for the prevention of invasive diseases.

The difference between this indicator and the extensiveness and intensity of invasion is that it does not reflect the number of invaded animals or the degree of their infection, it indicates the proportion of a particular pathogen that occurs in a particular farm. At the enterprises studied by us, protozoan diseases occupy a large share in cattle - 44.35; moniesioses in sheep - 27.61 .

Thus, the generic index of parasite cenosis is an indicator that can be used to identify not only the main share of each representative individually, but also to control the parasitic situation more objectively, which is a fundamental factor for the successful devastation of parasitic diseases of ruminants.

\section{Conclusion}

Based on the data obtained, it can be concluded that intestinal parasitoses of ruminants are ubiquitous on the territory of the Udmurt Republic and cover a fairly high percentage of the livestock. Other pathogens of invasive diseases are found mainly in isolated cases and their share in the structure of helminth cenosis is insignificant compared to the above-mentioned pathogens.

In the calculation of the extensiveness of cattle invasion, pathogens of protozoa diseases $(87.84 \%)$ and strongylatoses of the gastrointestinal tract $(62.58 \%)$ predominate, they are currently the main ones. In the structure of the parasite cenosis of cattle, the largest share is occupied by Eimeria spp - 44.35, Strongylata - 30.52, Dicrocoelium - 17.52, Fasciola - 6.43, to a lesser extent Eurythrema - 0.67 and Trichostrongylus -0.51 .

Sheep parasite cenosis is represented by a triad of representatives: moniesioses $(51.79$ $\%)$, strongyloidoses $(42.27 \%$ ) and eimerioses (49.40\%). The proportion of pathogens of other pathogens is insignificant and highly variable depending on the conditions of keeping animals. The parasite complex includes 6 consociates, the dominant shares belong to: Moniezia - 27.61, Strongyloides - 24.18, Eimeria spp - 24.79, a smaller share is occupied by: Fasciola - 12.48, Strongylata - 7.63, Dicrocoelium - 3.31.

\section{References}

1. E.S. Klimova, M.E. Mkrtchyan, T.V. Babintseva, A.D. Reshetnikova, Distribution of eimeria species and their associations in the farms of the udmurt republic, International Scientific and Practical Conference "AgroSMART-Smart Solutions for Agriculture". Ser. "KnE Life Sciences". 433-439 (2019)

2. N.I. Koshevarov, I.A. Arkhipov, Materials of the scientific conference of the All-Russian Society of Helminthologists of the Russian Academy of Sciences 11, 243-245 (2010)

3. V.A. Marchenko, E.A. Efremova, E.A. Vasilyeva, Russian Parasitological Journal 3, 14 (2008)

4. M.E. Mkrtchyan, Fundamental Research 10, 353-356 (2013)

5. R.I. Shangaraev, M.H. Lutfullin, N.A. Lutfullina, Russian Parasitological Journal 18-22 (2018)

6. J. Anyanwu, C. Iheanacho, L. Adogo, British Microbiology Research Journal 11, 1-8 (2016) doi.org/10.9734/BMRJ/2016/22358, https://publons.com/publon/1050614/

7. D.L. Brito, B.S.L. Dallago, H. Louvandini, V.R. Verdolin dos Santos, S.E. Figueirêdo de Araújo Torres, E.F. Gomes, A.F. Talamini do Amarante, C. Barros de Melo, C.M. McManus, Revista Brasileira de Parasitologia Veterinária 22 (4), 485-494 (2013) 
https://doi.org/10.1590/S1984-29612013000400007, https://www.scielo.br/j/rbpv/a/N yFX93hfJpVQzyv8qrT4gDn/?lang=en

8. G.C. Fthenakis, E. Papadopoulos, Small Ruminant Research 163, 21-23 (2018) https://doi.org/10.1016/j.smallrumres.2017.04.001, https://www.sciencedirect.com/sci ence/article/abs/pii/S0921448817300871?via\%3Dihub

9. T. Geurden, H. Hoste, P. Jacquiet, D. Traversa, S. Sotiraki, A. Frangipane di Regalbono, N. Tzanidakis, D. Kostopoulou, C. Gaillac, S. Privat et al., Veterinary Parasitology. 201, 59-66 (2014) https://doi.org/10.1016/j.vetpar.2014.01.016, https://www. sciencedirect.com/science/article/abs/pii/S0304401714000582?via\%3Dihub

10. F. Jackson, M. Varady, D.J. Bartley, Small Ruminant Research 103, 3-9 (2012) https://doi.org/10.1016/j.smallrumres.2011.10.012, https://www.sciencedirect.com/sci ence/article/abs/pii/S0921448811004263?via\%3Dihub

11. E.S. Klimova, M. Mkrtchyan, T.V. Babintseva, A.D. Reshetnikova, Yu. Kurskaya, BIO Web of Conferences, (FIES 2019). 00198 (2020)

12. F. Kenyon, F. Jackson, Veterinary Parasitology 186, 10-17 (2012) https://doi.org/10.1016/j.vetpar.2011.11.041 https://www.sciencedirect.com/science/ article/abs/pii/S0304401711007734?via\%3Dihub

13. A. Maurizio, L. Stancampiano, C. Tessarin, A. Pertile, G. Pedrini, C. Asti, W. Terfa, A. Frangipane di Regalbono, R. Cassini, Veterinary Sciences 8 (2021) https://doi.org/10.3390/vetsci8050069, https://www.mdpi.com/2306-7381/8/5/69/htm

14. I. Maqbool, Z.A. Wani, R.A. Shahardar, I.M. Allaie, M.M. Shah, Journal of Parasitic Diseases 41(1), 1-8 (2017) doi: 10.1007/s12639-016-0765-6, https://www.ncbi .nlm.nih.gov/pmc/articles/PMC5339188/

15. M.A. Muhammad, M.N. Muhammad, S. Noreen, Z. Muhammad, H. Muhammad, A. Mubashir, S.S. Ahsan, A. Atif, W. Abdul, Z. Aqal, M. Nasir, Goat Science, Sándor Kukovics, IntechOpen 13, 291-307 (2018) DOI: 10.5772/intechopen.74203, https://w ww.intechopen.com/chapters/59287

16. S.M. Rahman, A.R. Dey, U.K. Kundu, N. Begum, Journal of the Bangladesh Agricultural University 12, 79-85 (2014) doi.org /10.22004/AG.ECON.209900, https://publons.com/publon/32773779/

17. N.D. Sargison, Small Ruminant Research. 110, 78-81 (2013) https://doi.org/10.1016/j.smallrumres.2012.11.008, https://www.sciencedirect.com/sc ience/article/abs/pii/S0921448812004683?via\%3Dihub 